\title{
Health care of deaf persons during coronavirus pandemics
}

\author{
Atenção à saúde de pessoas surdas em tempos de pandemias por coronavírus \\ Atención a la salud de personas sordas en tiempos de pandemias por coronavirus
}

\section{Luana Paula de Figueiredo Correia' ORCID: 0000-0002-4543-0982 \\ Márcia de Assunção Ferreira' ORCID: 0000-0002-6991-7066}

'Universidade Federal do Rio de Janeiro. Rio de Janeiro, Rio de Janeiro, Brazil.

How to cite this article: Correia LPF, Ferreira MA. Health care of deaf persons during coronavirus pandemics. Rev Bras Enferm. 2022;75(Suppl 1):e20201036. https://doi.org/10.1590/0034-7167-2020-1036

Corresponding author: Luana Paula de Figueiredo Correia E-mail: luanafcorreia@gmail.com

EDITOR IN CHIEF: Dulce Barbosa ASSOCIATE EDITOR: Mitzy Dansk

Submission: $09-15-2020$

Approval: 05-10-2021

\section{ABSTRACT}

Objective: To reflect about the barriers experienced by the deaf population during the COVID-19 pandemic, the proposals to overcome communication barriers in health care and the role of public policies in effecting the social inclusion of deaf people. Methods: Reflection based on studies on health care for deaf people, the COVID-19 pandemic and public accessibility policies. Results: The global crisis of COVID-19 has deepened pre-existing inequalities in the world, in addition to highlighting the vulnerability of people with disabilities, including deaf. Government, institutional and social initiatives to mitigate difficulties in communicating to deaf people have been made, but they are still insufficient to guarantee protection for them in this pandemic and full inclusion in health care. Final considerations: Social inclusion, supported by law, and the linguistic accessibility of deaf people still need to generate broad and concrete actions so that deaf people can enjoy their rights as citizens.

Descriptors: Health Care; Deafness; Sign Languages; Pandemics; Coronavirus.

\section{RESUMO}

Objetivo: Dissertar sobre os entraves vivenciados pela população surda durante a pandemia de COVID-19, as propostas para superar as barreiras comunicacionais no atendimento em saúde e o papel das políticas públicas na efetivação da inclusão social de surdos. Métodos: Reflexão baseada em estudos sobre assistência à saúde da pessoa surda, pandemia de COVID-19 e políticas públicas de acessibilidade. Resultados: A crise global da COVID-19 tem aprofundado desigualdades pré-existentes no mundo, além de evidenciar a vulnerabilidade de pessoas com deficiência, entre elas as surdas. Iniciativas governamentais, institucionais e sociais para mitigar dificuldades na comunicação aos surdos têm sido feitas, mas ainda são insuficientes para garantir-lhes proteção nesta pandemia e plena inclusão nos cuidados de saúde. Considerações finais: A inclusão social, amparada por lei, e a acessibilidade linguística de surdos ainda necessitam gerar ações amplas e concretas para que as pessoas surdas possam usufruir dos direitos que lhes cabem como cidadãs.

Descritores: Atenção à Saúde; Surdez; Línguas de Sinais; Pandemias; Coronavírus.

\section{RESUMEN}

Objetivo: Disertar sobre los obstáculos vividos por la población sorda durante la pandemia de COVID-19, las propuestas para superar las barreras de comunicación en la atención sanitaria y el papel de las políticas públicas en la inclusión social efectiva de los sordos. Métodos: Es una reflexión basada en estudios sobre atención sanitaria de la persona sorda, COVID-19y políticas públicas de accesibilidad. Resultados: La crisis global de COVID-19 está profundizando las desigualdades preexistentes en el mundo, además de poner de manifiesto la vulnerabilidad de las personas discapacitadas, entre ellas las sordas. Se están llevando a cabo iniciativas gubernamentales, institucionales y sociales para mitigar las dificultades de comunicación de los sordos, pero todavía son insuficientes para garantizarles protección en esta pandemia y plena inclusión en la atención sanitaria. Consideraciones finales: Es necesario impulsar la inclusión social, respaldada por la ley, y la accesibilidad lingüística de los sordos con acciones amplias y concretas para que puedan disfrutar de sus derechos como ciudadanos.

Descriptores: Atención Sanitaria; Sordera; Lengua de Signos; Pandemias; Coronavirus. 


\section{INTRODUCTION}

The year 2019 had its beginning marked by an international emergency, caused by the New Coronavirus, designated by the World Health Organization (WHO) as Sars-Cov-2. This virus corresponds to the causative agent of the disease called COVID-19. Due to the accelerated spread of the virus among countries, on March 11, 2020, WHO declared COVID-19 as a pandemic.

The main routes of transmission are by droplets in the respiratory tract and by contact. Another route of transmission is through aerosols, and everyone is susceptible to contracting the virus. Older adults and people with chronic illnesses are at higher risk. The main symptoms are fever, fatigue and dry cough. A smaller proportion of patients also have other symptoms, such as nasal obstruction, runny nose and diarrhea. Most severe case patients, after a week of infection, have difficulty breathing ${ }^{(1)}$.

The global crisis of COVID-19 has deepened the pre-existing inequalities in the world. Recommendations for disease prevention include the use of masks, hand hygiene with water, soap or alcohol $70 \%$, in addition to social distancing ${ }^{(1)}$. Despite showing themselves as simple measures, the speed of dissemination and the number of deaths resulting from the disease have exposed relevant issues to be considered, such as the importance of collective government actions and the strong influence of social conditions on its outcome.

It is understood that the virus disproportionately affects population groups, with a higher risk for those with low socioeconomic status $^{(2)}$. This population faces a barrier in access to water, basic sanitation and personal protective equipment, configuring working conditions that interfere in meeting social distancing. In this context, vulnerable populations stand out, in which the difficulties of access to health preceded the pandemic, being accentuated. Among these, we have people with disabilities.

Even in so-called normal circumstances, people with disabilities are less likely to have access to health, care, education, employment and community participation. They are more likely to live in poverty, experiencing higher rates of violence, neglect and abuse, as well as being among the most marginalized in any community affected by the crisis. COVID-19 further aggravated this situation, with a disproportionate impact on this group, directly and indirectly ${ }^{(3)}$.

In the case of deaf people, the current situation represents a major challenge. Deaf people, when compared to hearing people, use health services less frequently, precisely because of the difficulty of welcoming and understanding in spaces. As a consequence, they tend to look for health centers when the disease is already installed, that is, for treatment ${ }^{(4)}$.

The main means of combat of COVID-19 corresponds to prevention. For this, the provision of financial conditions to the population to favor social distancing, as well as access to information, is essential. In addition, difficulties in communicating and disseminating information can impair health care for deaf people even more, which can lead to mistaken actions, promote fear and insecurity and impair the development of disease prevention actions.

\section{OBJECTIVE}

This study aims to talk about the barriers experienced by the deaf population during the COVID-19 pandemic, to highlight proposals to overcome communication barriers in health care and to highlight the role of public policies in effecting the social inclusion of deaf people.

\section{METHODS}

This is a reflection on health care for deaf people during the pandemic period of COVID-19. When delimiting the problem to be discussed, to subsidize the reflection, a non-systematic search for studies that dealt with the theme care for the deaf related to the health field was carried out, in the context of the New Coronavirus pandemic.

The search took place between May and July 2020, in the databases of the Virtual Health Library (VHL) and the US National Library of Medicine (PUBMED), using keywords such as Deafness or Deaf people or Sign Language, Health Car, New Coronavirus or COVID-19 or Coronavirus Pandemic. The title and summary of the articles were read, with the most relevant ones being selected, especially with regard to communication, based on two axes: the difficulties involving communicational accessibility, including the use of sign language in the health area; and the use of masks, the main personal protective equipment (PPE) that, in the context of the current pandemic, prevents lip reading and facial expressions. The authors' experience with regard to the health care of deaf people also contributed to the foundation of the reflection, in addition to the current public policies that deal with the social inclusion of this population group.

The reflection, substantiated by the selected studies, public policies and the authors' experience in relation to the theme, addressed the main problems faced by the deaf in the health field during the New Coronavirus pandemic and the proposals for overcoming the gaps pointed out.

\section{HEALTH CARE FOR DEAF PEOPLE DURING COVID-19}

To perform health care, it is essential to establish a form of communication that enables understanding and, from that, develop care by considering not only the clinical signs observed, but also what is exposed by the person to be cared for, welcoming them in this process. The health professional and the deaf person relationship has an interdiction from the moment that there is a difficulty in establishing communication between them, which harms the bond, the reception and the care itself.

Deaf people are those who have hearing loss and interact with the world through visual and sign language (SL) experiences, which in the case of Brazil is Libras ${ }^{(5)}$. What makes the difference between deaf people and people with hearing loss is that deaf people, in addition to sensory impairment, which in this case is hearing, add the visual experience of the world and their natural language, the sign language, composing the deaf community. This understanding of deaf people surpasses the clinical conception of deafness, marked by hearing loss, when considering cultural components.

Thus, it is worth noting that the inclusion of deaf people implies favoring visual experiences, promoting linguistic accessibility, mainly through the use of $\mathrm{SL}$, and attending to their communicational peculiarities. Thus, health care for deaf people 
still disappoints in terms of welcoming and accessibility. Professionals are unaware of the deaf community, knowing little about $\mathrm{SL}$ and the ways to establish inclusion during care ${ }^{(4)}$. Most health units are not adapted to overcome the language barriers imposed, having no visual signage to inform the call of deaf users, or to guide them as to the sectors that make up the care space ${ }^{(6)}$.

The difficulty of communication due to not sharing a common language, in addition to the professionals' lack of knowledge on ways to make communication easier, such as speaking slowly and well-articulated to deaf people who learned how to speak, or getting to know SL and the particularities of the writing of the majority language by deaf people, impacts the diagnosis, and may even cause mistakes in the treatment of diseases ${ }^{(4)}$. These situations generate distrust, frustration and lack of resolution for deaf users ${ }^{(6)}$.

With the COVID-19 pandemic, the problems experienced by deaf people in the health service were increased. The difficulty of obtaining information about the disease, accessing services, having accessibility to health care and humanization, which were previously evidenced, currently exposes how much we are in debt when it comes to the inclusion of deaf people in society and, mainly, in health.

With regard to access, information about the disease, such as the number of cases, deaths, ways to avoid contagion and treatment, are being widely disseminated in the media, mainly through newscasts. However, these newscasts do not have SL interpreters or audio description, so the information is not accessible to deaf people. At press conferences with representation from institutional bodies, such as health departments, there must be a Libras interpreter, which does not occur properly.

In Brazil, since 2015, the Brazilian Inclusion Law ensures linguistic accessibility in the field of information, communication and participation in politics. However, currently this accessibility is restricted to the official pronouncements of the President, mandatory electioneering and debates broadcast by television stations $^{(7)}$.

Social networks, such as facebook, instagram, youtube and whatsapp, have been accessible ways of disseminating information about COVID-19, in view of the initiative of universities, social movements of deaf people, deaf influencers and health departments that have made videos dealing with the theme using the SL. However, attention should be paid to the spread of fake news on the topic, checking frequently the reference of the information disseminated, if it is from a reliable source.

The Ceara State Department of Health, for example, held a web conference to answer questions from deaf people about COVID-19, with the participation of a SL user doctor. The Accessibility and Inclusion Center at the Federal University of Vale do Sao Francisco provided a series of videos transmitted live, accessible in Libras, to address issues associated with the pandemic. Also contributing to the dissemination of information, TV INES has focused on the New Coronavirus pandemic in its programming. This channel prioritizes Libras and has subtitles and voiceover, which integrates the deaf and hearing audiences, that is, offers bilingual programming.

Another pertinent aspect about the dissemination of information about COVID-19 in SL concerns the appropriate signaling to name the disease. It is important that the signals used to treat the New Coronavirus are standardized ${ }^{(8)}$. In Brazil, at least three signs are used to designate it, all of which are iconic, that is, when there is similarity between the object and the sign it represents. One of them was created in the beginning of the pandemic, when the virus was not deeply known, and suggests an animal bite, which can lead to misinterpretations about how to be infected with the New Coronavirus.

This misinterpretation is dangerous, as it can lead deaf people not to adopt preventive actions against the virus, but against animal bites, such as bats. The other two signals are directly related to the real agent of COVID-19, presenting details, such as shape and biological characteristics. It should be noted that the use of two or three signs forces the community and deaf interpreters to know all of them in order to have or give access to all information using $\mathrm{SL}^{(7)}$.

In addition, there are signs that the point of articulation may involve touching some part of the face, such as the mouth, forehead, for example, which goes against the preventive measures suggested by WHO, which advises to avoid touching the face, as one of the forms of protection against the New Coronavirus. It is essential that this information is widely disseminated to the deaf population, as it poses a risk of contamination.

With regard to communication during the provision of health care to deaf people, the use of masks is worth mentioning. If on the one hand they represent an ally in coping with COVID-19, on the other, they show adversity for deaf patients. Masks prevent lip reading and make it difficult to see facial expressions, which are fundamental when using SL. Furthermore, this PPE is uncomfortable for users of hearing aids and cochlear implants ${ }^{(9)}$.

As a solution to overcome some of these communication barriers, there is the use of transparent masks when attending the deaf user. The use of the transparent surgical mask improves the performance of speech perception in noise for people with hearing loss and does not negatively affect the performance of speech perception in noise. In addition, it makes it possible to visualize facial expressions and allows lip reading ${ }^{(10)}$. The investment of this type of PPE becomes essential, considering that possibly the use of a mask will be normalized, because so far there are no drugs for the treatment of COVID-19 with scientific evidence, in addition to the availability of vaccines for society to demand large period of time.

Linguistic accessibility to deaf people in health units is also achieved through the mediation of communication by SL interpreters. Although there is damage to the question of medical confidentiality and the autonomy of the deaf user in the healthdisease process, the interpreters assist in the communicative process, in cases where the health professional does not know $\mathrm{SL}$ and the deaf person does not know how to speak ${ }^{(6)}$. However, needing interpreters at the moment in the health services is putting more lives at risk, unless the translation is done remotely.

Another relevant issue corresponds to the lack of knowledge of health professionals about the deaf community, culture and identity, their health needs. Consequently, the understanding of this group can be based on beliefs and common sense, which can impair health care. Professionals often use lip reading, as well as writing, and believe that these means favor effective 
communication with deaf people. However, these strategies were considered inefficient for effective interaction, which makes communication between deaf people and health professionals difficult and, consequently, the full participation of those involved ${ }^{(4)}$.

It should be noted, despite being one of the most common forms of communication between health professionals and deaf people, that writing is not the best way to provide information to the deaf community, since they are presented in the main language of the country, in the case of Brazil, in Portuguese. SL has its own syntax and the order of words in the sentence is sometimes different from that of the oral modality. The use of SL allows the deaf community to access the technical language of communication, while enabling individual and collective care $\mathrm{e}^{(7)}$.

In an attempt to overcome language barriers, several solutions have been proposed internationally, such as providing call centers by video call, mobile applications and masks that are plastic in the mouth, but the application in the health unit is still limited, as they are innovations and, in the case of the mask, the production is still handcrafted. Tests are needed to verify their efficiency, and more research and actions are needed to provide effective solutions and global strategies ${ }^{(9)}$.

All the reported obstacles lead us to reflect on the need for public policies that establish the diffusion of SL in society with responsibility. It is necessary that the subject of Libras becomes mandatory in health courses, there must be more than one subject and has minimum driving guidelines. In addition, it is important that educational institutions fulfill their social responsibility and do not offer subjects only to comply with legislation. The objective of the course should be to train professionals qualified to use Libras during health care.

It is also necessary that $\mathrm{SL}$ be part of the permanent education policy of the Unified Health System - Sistema Único de Saúde (SUS), in the States and Cities, of the health units, whether they are primary care or medium and high complexity. It is necessary to expand research on the topic with students and professionals and users of the health system, so that the real needs of those involved and the care process are known. What is happening at that moment is a reflection of the neglect of more than 15 years of the publication of Decree 5626/2005, which in the health area has seen little result.

The entire pandemic process showed how important it is to have public policies, especially in the areas of health, work, economics, education and science. COVID-19 will leave its mark on society and it is up to the population to demand their governments with actions to overcome them and, above all, face the inequalities that the pandemic has exposed and aggravated. Finally, it is up to the government to effect the inclusion of people with disabilities in society, which is supported by law, as well as the linguistic accessibility of the deaf that has been guaranteed for more than 15 years in Brazil.

\section{Limitations of the study}

The scarcity of articles dealing with care to deaf people limits the debate on the topic. In addition, experimental research is needed to evaluate the use of masks with a transparent display, in addition to empirical research on continuing education and training of professionals in Libras, to verify the quality of these skills and their impact on the care of the deaf. Consideration should also be given to surveys at the health care points of reference in COVID-19 to find out about care for deaf people, in addition to knowing the experience of those who provided care and those who received it.

\section{Contributions to the area}

As potential contributions, it is envisaged to expand the discussion regarding the inclusion of deaf people in the health service, which despite having legal support for its implementation, still shows itself to be less than desired. This issue should be widely debated, with a view to sensitizing health professionals and managers, to overcome obstacles imposed on this population, which has been neglected for so long. The COVID-19 pandemic reinforced how urgent inclusive health guidelines are, so that we can finally welcome deaf people with empathy, establish a bond and fully assist them. To this end, this reflection can support new themes for the area of permanent health education.

In the academic field, this article can contribute to sensitize educational institutions to include sign language as a mandatory subject, to elaborate curricular proposals for training that considers respect for differences, in addition to encouraging research to deal with linguistic accessibility in the health field.

\section{FINAL CONSIDERATIONS}

The COVID-19 pandemic highlighted social distortions in the world. Vulnerable people tend to suffer the impacts of the disease more. Deaf people already face situations of social exclusion on a daily basis, as they do not have the right to communicate through the respected sign language and because there is a lack of linguistic accessibility.

It is no different in health, because the lack of knowledge about the deaf community and its natural language ends up impairing access and health care for them. In times of confrontation with COVID-19, deaf people have difficulty in obtaining information about the disease in the mass information vehicles, due to the lack of a SL interpreter, as well as difficulties in assistance, due to not knowing $\mathrm{SL}$, on the part of health professionals. and the use of protective masks that attenuate the intensity of the speech sound and reduce the visualization of facial expressions.

Social networks were of great importance in the dissemination of accessible information about COVID-19 to deaf people. Initiatives such as transparent masks to make the visualization of facial expressions easier also stood out. However, they are individual and punctual initiatives, highlighting the need for global actions, in addition to emphasizing the importance that the initiatives must be the responsibility of the public authorities, to ensure the reach of all.

The COVID-19 pandemic has impacted all of humanity and, in a more violent way, historically marginalized populations, such as people with disabilities. This event requires an unprecedented global response, with the commitment of government officials to guarantee access to essential services for people with disabilities. The world will never be the same again. So, it has to be inclusive, accessible and humanized for the entire population, without distinctions. 


\section{REFERENCES}

1. Zhang, W. Manual de Prevenção e Controle da Covid-19 segundo o Doutor Wenhong Zhang. São Paulo: PoloBooks; 2020.70 p.

2. Patel JA, Nielsen FBH, Badiani AA. Poverty, inequality and COVID-19: the forgotten vulnerable. Public Health. 2020;183:110-11. https://doi. org/10.1016/j.puhe.2020.05.006

3. United Nation. Policy brief: a disability inclusive response to COVID-19 [Internet]. ONU; 2020 [cited 2020 Jul 29 ]. 18 p. Available from: https:// unsdg.un.org/sites/default/files/2020-05/Policy-Brief-A-Disability-Inclusive-Response-to-COVID-19.pdf

4. Kuenburg A, Fellinger P, Fellinger J. Health care access among deaf people. J Deaf Stud Deaf Educ. 2016; 21(1):1-10. https://doi.org/10.1093/ deafed/env042

5. Presidência da República (BR). Decreto n 5.626, de 22 de dezembro de 2005. Regulamenta a Lei $n^{\circ}$ 10.436/2002, o art. 18 da Lei $n^{\circ}$ 10.098/2000, e dá outras providências [Internet]. Diário Oficial da União. 2005 [cited 2020 Dec 15]. Available from: http://www.planalto.gov. br/ccivil_03/_ato2004-2006/2005/decreto/d5626.htm

6. Souza MFNS, Araújo AMB, Sandes LF, Fonseca FDA, Soares WD, Vianna RS, et al. Main difficulties and obstacles faced by the deaf community in health access: an integrative literature review. Rev CEFAC. 2017;19(3):395-405. https://doi.org/10.1590/1982-0216201719317116

7. Presidência da República (BR). Lei no 13.146, de 6 de julho de 2015. Institui a Lei Brasileira de Inclusão da Pessoa com Deficiência [Internet]. Diário Oficial da União. 2015 [cited 2020 Jul 28]; Available from: http://www.planalto.gov.br/ccivil_03/_ato2015-2018/2015/lei/l13146.htm

8. Amorim G, Ramos A, Castro Jr G, Afonso L, Castro H. Coronavirus, deafness and the use of different signs of the area in health during a period of pandemic time: is that the best option to do?. Creat Educ. 2020;11(4):573-80. https://doi.org/10.4236/ce.2020.114042.

9. Trecca EMC, Gelardi M, Cassano M. COVID-19 and hearing difficulties. Am J Otolaryngol. 2020; 41(4):102496. https://doi.org/10.1016/j. amjoto.2020.102496

10. Atcherson SR, Mendel LL, Baltimore WJ, et al. The effect of conventional and transparent surgical masks on speech understanding in individuals with and without hearing loss. J Am Acad Audiol. 2017;28(1):58-67. https://doi.org/10.3766/jaaa.15151 